\title{
Epidermal Langerhans cells are critical for immunoregulation of cutaneous leishmaniasis
}

\author{
Heidrun Moll
}

\begin{abstract}
In leishmaniasis, macrophages are known to play a central role as modulators of the specific immune activity. In this article, Heidrun Moll presents evidence for the critical tnvolvement of another component of the skin immune system, the epidermal Langerhans cell. She proposes that Langerhans cells take up parasites in the skm and transport them to the draining lymph node for presentation to $T$ cells and intiation of the specific immune response.
\end{abstract}

Human leishmaniasis comprises a diverse group of diseases caused by protozoa of the genus Leishmana. The parasites belong to the family Trypanosomatidae; they alternate between the promastigote form in the sandfly vector and the obligatory intracellular amastigote form in the mammalian host. The diseases vary in severity from the naturally healing cutaneous leishmaniasis (oriental sore), which is characterized by a localized skin lesion at the site of the sandfly's bite, to the potentrally fatal visceral lesshmaniasıs (kala-azar), in which the parasites disseminate from the site of infection and invade lymph nodes, spleen, liver and bone marrow. The clinical manifestatıon depends primarily on the species of parasite, but it also involves the genetic basis of the host's ability to develop an effective cell-mediated immune response, thus resembling the situation in leprosy.

The spectrum of disease patterns seen in humans can be reproduced by experimental infection of mice with Letshmania major, the cause of cutaneous leishmaniasis in the Old World. This mouse model has provided a wealth of information on the immune mechanisms underlying host resistance or susceptiblity to leishmaniasis, with implications for a number of infectious diseases. The outcome of murne infection with $L$. major is not influenced by humoral immunity but appears to be determined by $C D 4^{+}$helper $T$ cells $\left(T_{H}\right.$ cells $)$ with different patterns of lymphokine activity. Thus, protertive immunity can be attributed to $T_{\mathrm{H}}$ 1-like cells producing interferon-gamma (IFN- $\gamma$ ), \%hereas $T_{H^{2}}$-like cells releasing interleukın 4 (IL-4) and IL-10 facilitate survival of the parasites ${ }^{1}$. On the other hand, the findings that $L$. major-specific $\mathrm{T}_{\mathrm{H}} 1$ cells can also exacerbate disease ${ }^{2}$ and that local injection of IL-4 has a therapeutic effect ${ }^{3}$ have emphasized the complexity of the interplay between the parasite and the host immune system.

\section{Early events in Leishmania infection}

Resistance to L. major infection can be induced in genetically susceptible mice by various treatments, for example, sublethal irradiation, immunizatıon with parasite antigen or treatment with anti-IL-4 antibodies. In most cases, however, such manipulations are only effective if performed before infection or during the first week, probably because the differential stimulation of ' $\mathrm{T}_{\mathrm{H}}$-cell subsets 15 initiated withun three days after inoculation of parasites. These findings emphasize the importance of the early phase of infection.

The natural site of entry of Leishmania parasites into the mammalian host is the skın. It is here that the organisms invade host cells for intracellular multtplication and are first encountered by the immune system. In view of the above observations, it is very likely that the cutaneous immune response at this initral stage of infection is crucial to the course of disease. Within a few hours after parasite inoculation, a massive cellular infiltration occurs consisting predominantly of macrophages which rapidly take up parasıtes'. The signals mediating the influx of macrophages may include chemotact:c cytokınes such as the monocyte chemoattractant protein, MCP-1 (R. Gillitzer, I. Becker and H. Moll, unpublished). On the basis of $m$ vitro and $m$ vivo studies, it is widely accepted that macrophages play a central role in lesshmaniasis ${ }^{6}$. They serve not only as host cells for the parasites, but also as antigenpresentıng cells mediatıng the stimulation of specific T cells. In return, lymphokines released by activated T cells regulate the antimicrobial potentral of macrophages which are the finai effector cells for limitation of the deleterious spread of parasites.

In the very early phase of infection with Lessbmanta, there are few $T$ cells in the dermal unfiltrate ${ }^{5}$. Thus, infected macrophages expressing parasite antigen have a low probability of encountering T cells with the corresponding specificity required for triggering the cellmediated immune response. It is necessary, therefore, to provide a principal sensitizing stgnal that activates antigen-specific quiescent $T$ cells in the lymphoid organs and induces their emigration via the bloodstream to the lesional skin. Furthermore, to allow for effective antigen presentation by macrophages, the 


\section{viewpoint}

surface expression of major histocompatibility complex (MHC) class II antigens has to be increased by stımulatory signals, such as IFN- $\gamma$, that are predominantly derived from activated $T$ cells?. These considerations indicate that macrophages may not suffice for induction and modulation of the cell-mediated immune reactivity to Leishmania parasites and other intracellular microorganisms invading the skin. In fact, the skin harbours cells with potent accessory capacity, epidermal Langerhans cells, which may represent the 'missıng link'.

\section{Langerhans cells - a component of the dendritic cell system}

Langerhans cells are derived from the bone marrow. They have a pronounced dendritic shape and can be identified, at the ultrastructural level, by organelles in their cytoplasm, termed Birbeck granules (reviewed in Ref. 8). Phenotypically, Langerhans cells share some features with macrophages since they express surface markers such as ATPase, nonspecific esterase and receptors for Fc and for complement. In contrast to macrophages, however, Langerhans cells (in the mouse) react with a monoclonal antibody directed against nonlymphoid dendritic cells (NLDC-145) (Ref. 9), and they constiturively express sizeable amounts of MHC class II molecules.

Langerhans cells are potent stimulators of antigenspecific and MHC-restricted T-cell responses ${ }^{10}$. Interestingly, their functional properties $m$ vitro are dependent on the state of differentiation ${ }^{11,12}$. Freshly isolated Langerhans cells can process native antigen for presentation to previously sensitized $\mathrm{T}$ cells, but are weak activators of resting $\mathrm{T}$ cells. During short-term culture, however, Langerhans cells lose their processing capacity and acquire the unique potentıal to induce primary immune responses. Thus, they become remarkably similar to the dendritic cells found in lymphoid organs ${ }^{13}$. These observations showed that cultured Langerhans cells are $\boldsymbol{m}$ vitro equivalents of Langerhans cells that have ingested and processed ant1gen in the skin and have then migrated to the draining lymph node while developing into lymphoid dendritic cells ${ }^{12,14}$. Indeed, this translocation of Langerhans cells has been documented in vivo after epicutaneous application of contact allergens $s^{15,16}$. It would be an efficient mechanism for transport of antigen from the site of first encounter in the skin to the drainıng lymph node where a large variety of $T$ cells can be found for initration of the specific immune response.

Evidence for a role of Langerhans cells in leishmaniasis

The function of Langerhans cells in vivo has been analysed using contact hypersensitivity and skın transplantation as convenient models. However, the involvement of Langerhans cells durıng infectious diseases is only established for viral infections, such as human immunodeficiency virus and herpes simplex virus. With regard to skin-borne diseases caused by intracellular bacteria or parasites, there are reports on the distribution and rurnover of Langerhans cells ${ }^{17-19}$, but their function has not been defined. Attempts to address this issue by performing manipulations that result in an alteration of Langerhans cell density in the skin (for example, ultraviolet B irradiation, tape strıpping or sterold treatmentl have produced conflictıng results depending on the type of infectious agent and the mode of treatment ${ }^{19-21}$. Furthermore, the contribution of Langerhans cells to the observed effects is difficult to evaluate because those treatments also affect other components of the skin immune system.

\section{Parasite ingestion by Langerhans cells}

We have assessed the function of Langerhans cells in experimental cutaneous leishmanıasis with $L$. major. Although Langerhans cells are considered to be minimally phagocytic, they express receptors for the complement component $\mathrm{C} 3 \mathrm{bi}$ (CR3), which opsonizes Letshmania parasites for macrophages ${ }^{22,23}$. This would favor the idea that they can interact with these organisms. Indeed, Langerhans cells were able to phagocytose intact parasites $m$ vitro and $m v i v o^{24}$. Ingestion of L. major could be detected only after incubation of amastigotes with freshly isolated Langerhans cells, but not with those cultured for more than $12 \mathrm{~h}$ (suggesting that only intracutaneous Langerhans cells display this activity) and was mediated by the CR3. Thus, it is conceivable that phagocytic activity is not a general feature of a given cell type, but a property dependent on the state of differentiation and on expression of the receptors that are required for interaction with the respective particle. In this context, it is of interest that Reis e Sousa and Austyn ${ }^{25}$ have recently provided evidence for the ability of Langerhans cells to phagocytose zymosan, the uptake of which correlated with the activity of the mannose receptor. Together, these findings unambiguously show that Langerhans cells are able to take up particles of considerable size.

\section{Presentation and transport of L. major by Langerhans cells}

As compared with macrophages, the rate of infection and the parasite load of $L$. major-containing Langerhans cells was consistently low. This supports the notion that phagocytosis of L. major by Langerhans cells is not aimed at clearance of parasites but at acquisition of antigen for presentation to $\mathrm{T}$ cells. Such a concept is in concordance with our finding that epidermal Langerhans cells are potent stimulators of $L$. majorspecific $\mathrm{T}$-cell proliferation and lymphokine production in vitro ${ }^{26}$. In this respect, their activity was found to be much greater than that of macrophages.

In the course of infection with $L$. major, a dramatic change in the distribution of Langerhans cells was observed $^{24.27}$. A cunsiderable loss of NLDC-145* Langerhans cells in the segment of the epidermis overlying the parasite-containing infiltrate was concomitant with the appearance of NLDC- $145^{+}$cells in the dermal layer of the lesion, some of which contained L. major. Langerhans cells of the epidermis were found not to be parasitized. These observations strongly suggest that Langerhans cells migrate from the epidermis to the site of infection in the dermis for uptake of L. major parasites. Furthermore, it was possible to demonstrate directly by in vivo tracking that epidermal 


\section{viewpoint}

Langerhans cells infected with $L$. major have the ability to migrate from the skin to the draining lymph node ${ }^{2}$. Such a translocation was not seen with infected macrophages under similar conditions. The migratory lymph node dendritic cells presented the transported antigen to $L$. major-primed $T$ cells in vitro and, most notably, activated resting $T$ celıs capable of mediatıng a parasite-specific delayed-type hypersensitivity response in vivo.

\section{The model}

On these grounds, 1 propose a central role for Langerhans cells in the early phase of leishmaniasis (Fig. 1). Upon inoculation of Letshmania into the skin, Langerhans cells migrate from the epidermis to the dermis and take up parasites. The signals inducing this translocation may be mediated by hostderived cytokines, such as IL-1 $\beta$ (Refs 28,29 ) or tumor necrosis factor- $\alpha$ (Ref. 30) and/or by parasite-denved molecules. Whereas macrophages serve as scavengers and are the predominant site of parasite replication, the primary function of infected Langerhans cells appears to be the transport of organisms to the draining lymph nodes where they encounter a large variety of $\mathrm{T}$ cells with different specificities. During migration, the Langerhans cells develop into potent antigenpresenting cells with the ability to stimulate selected, but immunologically naive, $\mathrm{T}$ cells for initiation of the immune response. As a result, activated $T$ cells with specificity for Leishmanta antigens would emigrate via the blood into the lesion. At this site, infected macrophages as well as parasite-containing Langerhans cells that remained in the dermis are likely to present antigen to infiltrating $T$ cells and regulate their effector activity, a process that may be enhanced by cascades of locally produced cytokines.

At this point, the question anses whether Langerhans cells should be considered merely as a functional alternative to macrophages in leishmaniasıs. Several considerations argue against this supposition: (1) the migratory property of Langerhans cells is a distinctive feature that equips them to act as an outpost of the immune system; (2) Langerhans cells have the capacity to present antigen to $T$ cells with extraordinary efficiency; and (3) Langerhans cells have the unique ability to induce the primary activation of antigenspecific $T$ cells.

Thus, the involvement of Langerhans cells in initial events after infection may be a prerequisite for development of the specific cellular immune response. At later stages of infection, the remarkable ability of Langerhans cells to cluster high numbers of memory/effector $\mathrm{T}$ cells within the $\mathrm{skm}^{31}$ may be important for maintenance of an effective response. On the other hand, macrophage functions are complementary to those of Langerhans cells in leishmaniasis. Their scavenger activity and abılity, after appropriate activation, to produce high amounts of reactive oxygen and nitrogen metabolites emphasizes their role as the ultimate effector cells during clearance of infection ${ }^{32}$. It has yet to be determined whether Langerhans cells use sımilar mechanısms to control intracellular replication of parasites.

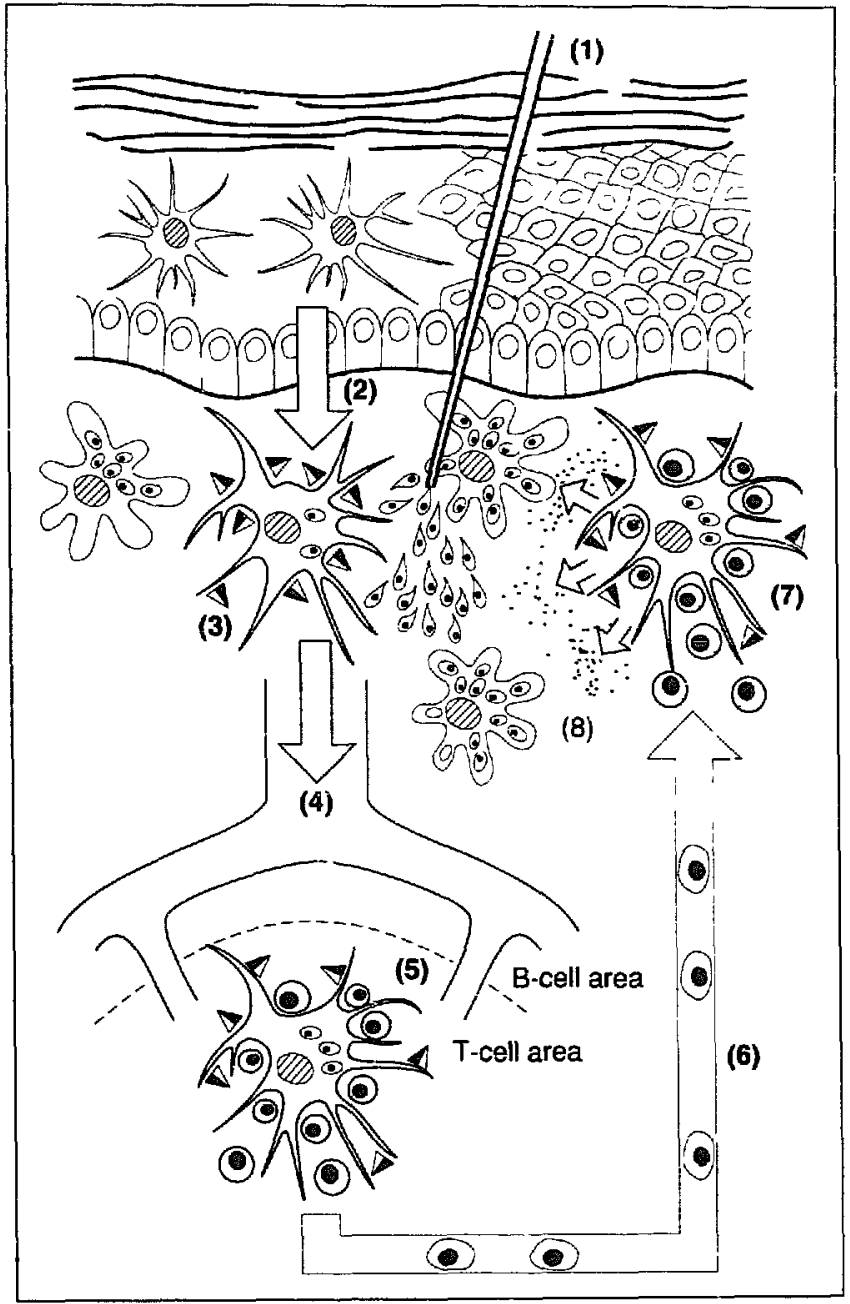

Fug. 1. Hypothotical model of the functional acturtes of Langerbans cells m cutaneous letshmaniasts. After depostton of Lesshmania promastigotes in the skin by $a$ sandfly or by expertmental infection (1), Langerhans cells migrate from the epidermis to the derms (2) and, like macrothages, take up parasites (3) Appropriate processing results $m$ expression of parasite antigen associated with MHC class II molecules on the cell surface ( 4 ). A proportion of Langerhans cells transports parasites from the infected skm to the draining lymph node (4) for presentation to antigen-specific resting $T$ cells in the paracortex (5). As a result, actwated $T$ cells emigrate wa the blood into the lesion (6). where infected macrophages and Langerhans cells that reman in the dermis (7) regulate their effector acturty by several mechanisms including cytokine secretion (8)

\section{Implications for the course of disedse}

On the basis of the findings discussed above, there are several important implications for our understanding of the pathogenesis of cutaneous leishmaniasis. First, with reference to the development of $T_{H^{-}}$cell subsets producing different arrays of lymphokines. It has been suggested that the type of antigen-presenting cell determines the phenotype of responding $T$ cells ${ }^{33-35}$. The described activities of Langerhans cells, however, can be detected in resistant and in susceptible mice, although we observed differences in the rate of infection (H. Moll, unpublıshed). In fact, the Initıal predominance of $L$. major-bearing dendritic cells in lymph nodes draming the lesions of both types of mice ${ }^{27}$ may explain our previous observation that, at the early 


\section{viewpoint}

stage of infection, those organs contain a comparable frequency of IL-4-secretıng cells ${ }^{36}$.

It is possible that the relative frequencies of different types of antigen-presenting cells, resulting in different densities of ligands ( $\mathrm{MHC}$ class II-peptide) for the T-cell receptor, may influence the phenotype of responding $\mathrm{T}$ cells ${ }^{3{ }^{3}}$. In addirion, the development of T-cell subsets $i n$ vivo may not be restricted exclusively by the antigen-presenting cell, but may be influenced by the availability of co-stımulatory signals (for example, cytokines) from other cell types in the microenvironment ${ }^{38.39}$.

A second implication relates to the role of parasite antigens. The various types of accessory cells may differ in their processing machınery and may thus favor the presentation of distinct antigens or particular epitopes of a given antigen. For example, freshly isolated Langerhans cells reflecting the intra-epidermal stage were found to display numerous acidıc organelles that are probably involved in antigen processing ${ }^{40}$. These organelles virtually disappear in cultured Langerhans cells - those that resemble lymph node dendritic cells and have lost the ability to process native proteins, but retain the ability to present peptides ${ }^{11,40}$. Furthermore, MHC class II molecules are more stable and synthesis of invariant chain is increased in Langerhans cells as compared with macrophages ${ }^{41}$. The slow turnover of MHC class II molecules is of particular interest because it enables antigen-laden dendritic cells to retain immunogenic peptides during migration ${ }^{14}$. Thus, It may be possible to charge Langerhans cells with purified parasite antigen ex vivo for immunization and induction of a protective $\mathrm{T}$-cell response in st $u$. Certainly, a more detalled knowledge of these issues will be important for choosing the route and the mode of administration of protective antigens and, thus, the development of new vaccination strategies.

Finally, it will be of interest to analyse the mechanısms underlying the disparate permissıveness of resıdent macrophages and Langerhans cells to infection with L. major and possibly other Leishmania species. This may help to understand the varying disease patterns caused by different species of parasites and to approach the well-documented phenomenon of parasite persistence in immune hosts.

I am indebted to Drs H.U. Beuscher, C. Bogdan, R. Gillitzer and Prof. W. Solbach for their critical and constructive comments on this manuscript and to Prof. $M$. Rollinghoff for most valuable discussions and continuous support throughout this work. This project is supported by the Deutsche Forschungsgemennschaft.

Heidrun Moll is at the Institute of Clintcal Microbiology, Unverstty of Erlangen-Nurnberg, Post fach 2069, 91010 Erlangen, Germany.

\section{References}

1 Locksley, R.M. and Scott, P. (1991) in Immunoparasitology Today (Ash, C. and Gallagher, R.B., eds), pp. A58-A61, Elsevier Trends Journals 2 Titus, R.G., Muiller, I., Kımsey, P. et al. (1991) Eur. J. Immunol. 21, 559-567

3 Carter, K.C., Gallagher, G., Ballie, A.J. and Alexander, J.
(1989) Eur. J. Immunol. 19, 779-782

4 Scott, P. (1991) J. Immunol. 147, 3149-3155

5 Andrade, Z.A., Reed, S.G., Roters, S.B. and Sadigursky, M. (1984) Am. J. Pathol. 114, 137-148

6 Solbach, W., Moll, H. and Rollinghoff, M. (1991)

Immunol. Today 12, 4-6

7 Steeg, P.S., Moore, R.N., Johnson, H.M. and Oppenheim, J.J. (1982) J. Exp. Med. 156, 1780-1793

8 Schuler, G. (ed.) (1990) Epidermal Langerhans Cells, CRC Press

9 Kraal, G., Breel, M., Janse, M. and Bruın, G. (1986)

J. Exp. Med. 163, 981-997

10 Stingl, G., Katz, S.I., Clement, L., Green, I. and Shevach, E.M. (1978) ]. Immunol. 121, 2005-2013

11 Romanı, N., Koide, S., Crowley, M. et al. (1989) J. Exp. Med. 169, 1169-1178

12 Streılein, J.W., Grammer, S.F., Yoshikawa, T., Demıdem, A. and Vermeer, M. (1990) Immunol. Rev. 117, 159-183

13 Schuler, G. and Steinman, R.M. (1985) J. Exp. Med.

$161,526-546$

14 Steinman, R.M. (1991) Annu. Rev. Immunol. 9, 271-296

15 Macatonıa, S.E., Knıght, S.C., Edwards, A.J., Grıffıths, S. and Fryer, P. (1987) J. Exp. Med. 166, 1654-1667

16 Kripke, M.L., Munn, C.G., Jeevan, A., Tang, J-M. and Bucana, C. (1990) J. Immunol. 145, 2833-2838

17 Collıngs, L.A., Waters, M.F.R. and Poulter, L.W. (1985)

Clin. Exp. Immunol. 62, 458-467

18 Kaplan, G., Nusrat, A., Witmer, M.D., Nath, I. and Cohn, Z.A. (1987) J. Exp. Med. 165, 763-776

19 Cáceres-Dittmar, G., Sánchez, M.A., Orıł, O., Kraal, G. and Tapia, F.J. (1992) J. Invest. Dermatol. 5?, 95S-98S

20 Gianninı, S.H. (1992) Parasttol. Today 8, 44-48

21 Jeevan, A., Evans, R., Brown, E.L. and Krıpke, M.L. (1092) J. Invest. Dermatol. 99, 59-64

22 Blackwell, J.M., Ezekowitz, A.B., Roberts, M.B. et al. (1985) J. Exp. Med. 162, 324-331

23 Mosser, D.M. and Edelson, P.J. (1985) J. Immunol. 135, 2785-2789

24 Blank, C., Fuchis, H., Rappersberger, K., Rollınghoff, M. and Moll, H. (1993) J. Infect. Dis. 167, 418-425

25 Reis e Sousa, C. and Austyn, J.M. (1993) in Dendritic Cells in Fundamental and Clinical Immunology (Hoefsmit, E.C.M., Nieuwenhuss, P. and Kamperdık, E.W.A., eds), pp. 129-204, Plenum Press

26 Will, A., Blank, C., Rollinghoff, M. and Moll, H. (1992) Eur. J. Immunol. 22, 1341-1347

27 Moll, H., Fuchs, H., Blank, C. and Rollinghoff, M. Eur. J. Immunol. (in press)

28 Nylander-Lundqvist, E. and Back, O. (1990) Acta Derm. Venereol. (Stockholm) 70, 391-394

29 Enk, A.H., Angelon, V.L., Udey, M.C. and Katz, S.I (1993) J. Immunol. 150, 3698-3704

30 Cumberbatch, M. and Kumber, I. (1992) Immunology $75,257-263$

31 Silberberg, I. (1971) J. Invest. Dermatol. 64, 37-51

32 Liew, F.Y. and Cox, F.E.G. (1991) in

Immunoparastology Today (Ash, C. and Gallagher, R.B., eds), pp. A17-A21, Elsevier Trends Journals

33 Gajewskı, T.F., Pinnas, M., Wong, T. and Fitch, F.W. (1991) J. Immunol. 146, 1750-1758

34 Chang, T-L., Shea, C.M., Urioste, S. et al. (1990)

J. Immunol. 145, 2803-2808

35 Schmitz, J, Assenmacher, M. and Radbruch, A. (1993)

Fur. J. Immunol. 23, 191-199

36 Moll, H. and Rollinghoff, M. (1990) Eur. J. Immunol. 20, 2067-2074

37 Pfeiffer, C., Murray, J, Madrı, J. and Bottomly, K. (1991) Immunol. Rev. 123, 65-84 


\section{viewpoint}

38 Hsıeh, C-S., Heımberger, A.B., Gold, J.S., O'Garra, A and Murphy, K.M. (1992) Proc. Natl Acad. Sa. USA 89, 6065-6069

39 Seder, R...., Paul, W.E., Davis, M.M. and

Fazekas de St Groth, B. (1992) J. Exp. Med. 176,
$1091-1098$

40 Stossel, H, Koch, F., Kampgen, E. et al. (1990) J. Exp. Med. 172, 1471-1482

41 Kampgen, E., Koch, N., Koch, F. et al. (1991) Proc. Natl Acad Sat. USA 88, 3014-3018 